\title{
Internal Carotid Dissection as the Cause of Stroke in Childhood
}

\author{
Giulia Cinelli $\mathbb{D},{ }^{1}$ Vitaliana Loizzo $\triangle{ }^{1}{ }^{1}$ Lisa Montanari $\left(\mathbb{D},{ }^{1}\right.$ Ilaria Filareto $\mathbb{D},^{1}$ \\ Elisa Caramaschi $(\mathbb{D}), 2$ Barbara Predieri $\mathbb{D}^{1},{ }^{1,2}$ and Lorenzo Iughetti $\mathbb{D}^{1,2}$ \\ ${ }^{1}$ Post Graduate School of Pediatrics, Department of Medical and Surgical Sciences of the Mothers, Children and Adults, \\ University of Modena and Reggio Emilia, Largo del Pozzo 71-41124, Modena, Italy \\ ${ }^{2}$ Pediatric Unit, Department of Medical and Surgical Sciences of the Mothers, Children and Adults, \\ University of Modena and Reggio Emilia, Largo del Pozzo 71-41124, Modena, Italy \\ Correspondence should be addressed to Barbara Predieri; barbara.predieri@unimore.it
}

Received 12 February 2021; Accepted 21 June 2021; Published 29 June 2021

Academic Editor: Bibhuti Das

Copyright ( 2021 Giulia Cinelli et al. This is an open access article distributed under the Creative Commons Attribution License, which permits unrestricted use, distribution, and reproduction in any medium, provided the original work is properly cited.

\begin{abstract}
Internal carotid artery (ICA) dissection is a cause of stroke, but it is often underdiagnosed in children. ICAs' risk factors and pathogenic mechanisms are poorly understood, and the treatment is still empirical. We report the case of a previously healthy 9 year-old girl who presented with involuntary hypertonic closure of the right hand associated with transient difficulty for both fine movements of the right arm and speech. She had a history of minor cervical trauma occurring 20 days prior to our observation without other associated risk factors. Magnetic resonance imaging and magnetic resonance angiography showed ischemic lesions due to the left ICA dissection. Treatment with both acetylsalicylic acid and levetiracetam allowed recanalization of the ICA associated with the resolution of clinical signs. Our clinical case suggests that the ICA dissection must be suspected early whenever a child manifests mild neurologic deficits after a cervical trauma, especially if they are associated with headache and/or cervical pain. Moreover, the management of ICA dissection must be improved.
\end{abstract}

\section{Introduction}

Stroke is rare in childhood, but it involves severe morbidity and mortality. Congenital and acquired hearth diseases, vasculopathies, infections, genetic conditions, and metabolic disorders are the most common etiologic causes of strokes $[1,2]$ that can also occur after the dissection of cerebral vessels. Carotid artery dissection (CAD) accounts for $7.5-20 \%$ of ischemic strokes' causes [3, 4], and its recurrence in affected patients increases over time after the index event (5\% at 1 month, $10 \%$ at 3 months, $12 \%$ at $6-12$ months, and $15 \%$ at 60 months) [5]. Traumatic events, predisposing genetic conditions such as collagenopathies or states of hypercoagulability, and spontaneous dissections are risk factors for CAD development [6, 7]. Associated clinical signs are generally acute, mainly represented by visual disturbances, nausea, vomiting, headache, hemiparesis, and ataxia [8]. The magnetic resonance imaging (MRI) is firstly performed in order to detect the CAD and the brain damage, thereafter, during the follow-up $[9,10]$.
The American Heart Association/American Stroke Association reported guidelines for adults' stroke management [11] and provided indications for the clinical practice in children [12]. Published clinical trials recommended a therapeutic approach with antiplatelet and/or anticoagulant drugs $[13,14]$. However, the usefulness of the antiplatelet therapy in patients with intracranial dissection is still controversial, and no consensus is still available on the duration of the anticoagulation therapy [1].

We report the case of a pediatric stroke due to CAD, characterized by neurological focal signs that occurred about 20 days after a minor cervical trauma.

\section{Case Presentation}

A 9-year-old girl was admitted to our Pediatric Emergency Clinic because of brief involuntary hypertonic closure of her right hand, followed by transient difficulties in fine hand movements and in speech. These symptoms were also reported two weeks earlier, while other ones, such as headache, 
vomiting, and seizures, never appeared. The recent history was negative for severe traumas or injuries, while a mild cervical trauma occurred 20 days earlier due to the impact with the volleyball during the gym lesson. Her anamnesis was unremarkable, except for intermittent asthma and multiple allergen sensitization (dust mites, pollen, and canine grass), but no acute or chronic treatment was ongoing at the evaluation time. Family medical history was silent, except for one sister suffering from frequent vasovagal syncopal episodes, as documented by the tilt test. Specifically, connective tissue diseases or young onset strokes were not reported. At hospital admission, her body temperature, blood pressure, and other vital signs were in range according to age. Cardiopulmonary and abdominal physical examination was unremarkable. At the neurological examination, we found that tone, muscle trophism, strength, fine motility, and coordination were normal, as well as pupils were both same and normally reactive to the light. The evaluation of cranial nerves was normal. Romberg test, nose index test, and tightrope walker test were correctly performed. Reflexes were normal and symmetric. She did not refer sensitivity deficit. Laboratory test, including inflammatory markers and coagulation profile, resulted within the normal range (Table 1). In order to exclude epileptic seizures, the electroencephalogram (EEG) was performed, and a subcontinuous slow high-voltage activity focused on the left front-central regions was found (Figure 1). Brain MRI and magnetic resonance angiography (MRA) were performed for a better diagnostic definition, and hyperintense alterations of the frontoparietal signal, extended to the corpus callosum, were found in long-TR sequences (Figure 2(a)). These findings were consistent with a recent ischemic lesion. Another ischemic lesion in the late subacute phase was identified at the ipsilateral pale. There was no evidence of acute or chronic hemorrhage in both the subarachnoid space and the brain parenchyma. The MRA study showed both the tightened stenosis of the left internal carotid artery (ICA) and the thinning and irregularity of the left middle carotid artery (MCA), data that allowed us to diagnose the left ICA dissection (Figure 2(b)). The patient was then treated with acetylsalicylic acid (ASA, $100 \mathrm{mg} /$ day) as antiplatelet therapy and with levetiracetam (up to $40 \mathrm{mg} / \mathrm{kg} /$ day) as antiepileptic therapy. The MRI was repeated 5 days after the therapy was started, and it showed an almost complete revascularization of both the carotid siphon and the left ICA, except for its lower cervical tract. The progressive revascularization of arteries was confirmed at subsequent MRI controls performed at 3, 12, and 24 months. Specifically, the MRI performed 24 months after the diagnosis showed the stability of the malacic-gliotic outcome of the frontal ischemic lesion and slightly reduced the caliber of the left ICA. During hospitalization, echocardiography, including the bubble study, was also performed to exclude malformations, mainly the patent foramen ovale and heart valve disorders. The autoimmune screening including antinucleous antibodies, neutrophil antigranulocyte antibodies, and rheumatoid factor was negative. Complement factors (C3 and C4) were in the normal range as well as homocysteine levels. The coagulation screening showed only lupus anticoagulant transient positivity (negative 12 weeks later). No mutation of the prothrombin gene, factor $\mathrm{V}$ Leiden, and von Willebrand was found. Finally, we excluded genetic connective tissue disorders such as Loeys-Dietz and Ehlers-Danlos syndromes. The patient was discharged after 15 days of hospitalization without clinical signs or symptoms. At the time of the submission of this case report, she is still in antiplatelet (ASA, $50 \mathrm{mg} /$ day) and antiepileptic (levetiracetam, $45 \mathrm{mg} /$ $\mathrm{kg} /$ day) treatment. After 24 months from diagnosis, her neurological examination is normal, and she complains only occasional headache. She is attending school with a good profit and socialization. Her follow-up is going to include clinical examination every 6 months, while MRI and echo color Doppler imaging of carotid vessels are going to be carried out every 12 months.

\section{Discussion}

Brain and neck CADs are major causes of cerebrovascular injuries in children $[3,4]$, and they may be spontaneous (commonly intracranial) or traumatic (commonly extracranial) [15]. The most common mechanism in traumatic CAD is direct blows to the neck/head or hyperextension $[8,9,16]$. Specifically, sudden acceleration/deceleration and rotation of the neck can stretch and compress the ICA causing dissection [6]. Different trauma types related to ischemic stroke cases are reported in Table $2[4,6,7,16-27]$, and it must be remembered that the trauma may be mild or even unnoticed $[4,5]$. Sports, fights, and falls can cause $\mathrm{CAD}$, but motor vehicle accidents play the most important role [8]. The annual incidence of spontaneous CAD was reported from 2.6 to $3.0 / 100,000$ subjects [28]. Moreover, several other causes of spontaneous CAD were described, such as infection (i.e., varicella-zoster virus and pharyngeal infections), hereditary connective tissue disorders (i.e., Ehlers-Danlos syndrome), Moyamoya disease, arteriopathies, fibromuscular dysplasia, atherosclerosis, and cystic medial necrosis $[4,8,29]$.

In our case, the patient reported only a mild cervical trauma that occurred about 20 days before symptoms' onset. No coagulation risk factors, connective tissue disorders, family history for coagulopathy, or dissection were found. The CAD can have different clinical presentations during childhood according to the cerebral site involved by the hypoperfusion. Neurologic signs could appear weeks after the trauma [19]. Moreover, hemiparesis, headache, aphasia, dysphasia, anopsia, and altered level of consciousness can frequently occur in affected patients [8]. In children, seizures were also observed, unlike in adults, while prodromal signs of upcoming acute ischemic stroke (just as transient ischemic attacks, amaurosis fugax, or local symptoms) were not frequently reported [12]. Our patient complained of mild, transient, and recurrent neurological symptoms. She had no seizures, and her neurological evaluation was normal.

Angiography is the gold standard for the CAD diagnosis; however, it is not often performed in children because arterial vascular access, general anesthesia, and ionizing radiation are needed to perform the exam. Nevertheless, MRI 
TABle 1: Patient laboratory data at the admission time.

\begin{tabular}{|c|c|}
\hline Coagulation function & $\begin{array}{l}\text { (i) PT ratio: } 1.02 \text { (range: } 0.84-1.20 \text { ) } \\
\text { (ii) PT INR: } 1.02 \text { (range: } 0.84-1.25 \text { ) } \\
\text { (iii) APTT ratio: } 1.03 \text { (range: } 0.80-1.25 \text { ) } \\
\text { (iv) Fibrinogen: } 307 \mathrm{mg} / \mathrm{dl} \text { (range: } 200-400 \text { ) } \\
\text { (v) Homocysteine level: } 7.28 \mu \mathrm{mol} / \mathrm{L} \text { (range: } 5-12 \text { ) } \\
\text { (vi) Lupus anticoagulant research: positive } \\
\text { (vii) Activated protein C resistance: negative } \\
\text { (viii) Protein S: } 0.77 \mathrm{U} / \mathrm{ml} \text { (range: } 0.53-1.09 \text { ) } \\
\text { (ix) Mutation of factor V Leiden: negative } \\
\text { (x) Mutation of factor II: negative }\end{array}$ \\
\hline Autoimmune investigations & $\begin{array}{l}\text { (i) Complement factor } \\
\text { (1) C3: } 131 \mathrm{mg} / \mathrm{dl} \text { (range: } 80-190 \text { ) } \\
\text { (2) C4: } 15 \mathrm{mg} / \mathrm{dl} \text { (range; } 15-57 \text { ) } \\
\text { (ii) Rheumatoid factor: } 11 \mathrm{UI} / \mathrm{L} \text { (normal value: <20) } \\
\text { (iii) Antinucleous antibodies: negative } \\
\text { (iv) Neutrophil antigranulocyte antibodies: negative } \\
\text { (v) Anti-beta2glicoprotein IgG: } 1.4 \mathrm{U} / \mathrm{ml} \text { (positive value: }>10 \text { ) } \\
\text { (vi) Anti-beta2glicoprotein IgM: } 0.6 \mathrm{UI} / \mathrm{ml} \text { (positive value: }>10 \text { ) } \\
\text { (vii) Anticardiolipin IgG: } 1,3 \mathrm{GPL}-\mathrm{U} / \mathrm{ml} \text { (positive value: }>40 \text {; low positive range: } 10-40 \text { ) } \\
\text { (viii) Anticardiolipin IgM: } 1,3 \mathrm{MPL}-\mathrm{UI} / \mathrm{ml} \text { (positive value: }>40 \text {; low positive range: } 10-40 \text { ) }\end{array}$ \\
\hline
\end{tabular}

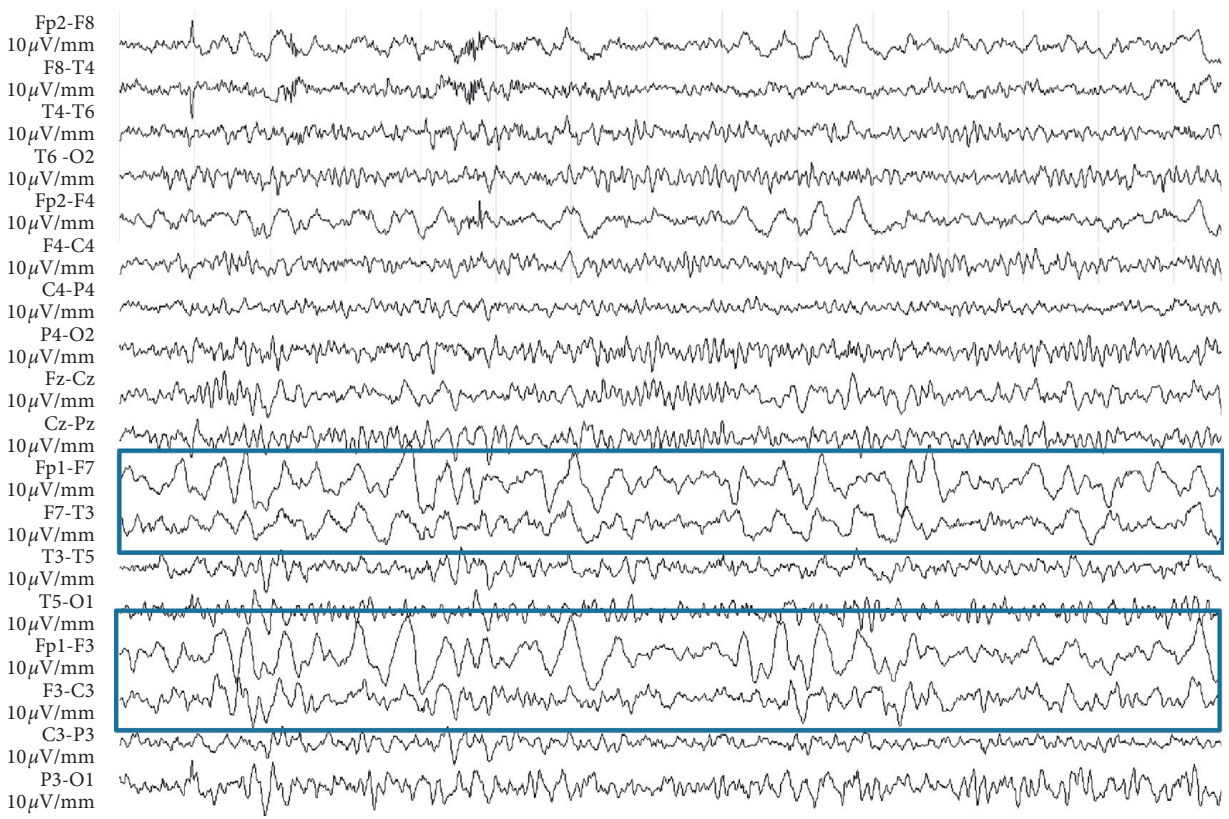

FIgURE 1: EEG pattern at the admission time-subcontinuous slow high-voltage activity focused on the left front-central regions.

and MRA were described to be sensitive and specific as angiography. Specifically, MRI allows to detect acute ischemic stroke through a noninvasive diagnostic approach, giving a faster and safer diagnosis $[9,10]$. In our case, despite the lack of typical seizures, we firstly performed the EEG, while MRI/MRA was performed thereafter, also according to the EEG result.

To date, efficacy and safety of the antithrombotic treatment (anticoagulants or antiplatelets) in patients with intracranial artery dissection are not yet assessed in randomized controlled trials, systematic reviews, and metaanalyses of observational data. Probably, mechanisms of cerebral ischemia in intracranial artery dissection are the same as those of cerebral ischemia in cervical artery dissection [29]. Markus et al. [14], in a trial including 250 adult patients (aged from 18 to 87 years) with cervical artery dissection, demonstrated that antiplatelet (mostly ASA) and anticoagulant drugs had the same efficacy for the prevention of stroke and death. ASA was also recommended for secondary prevention after transient ischemic attack (TIA) or ischemic stroke according to the trial data, showing a 13\% reduction in the long-term risk of recurrent stroke. However, the risk of major stroke is very high only few days after TIA and minor ischemic stroke. Studies showed substantially great benefits of the early medical treatment in the acute phase [13]. In our patient, we decided to start with the antiplatelet therapy, assuming that thromboembolism was the cause of site stroke secondary to the CAD and taking into 


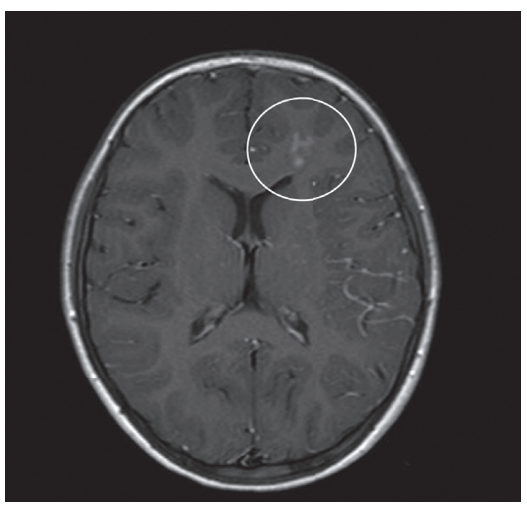

(a)

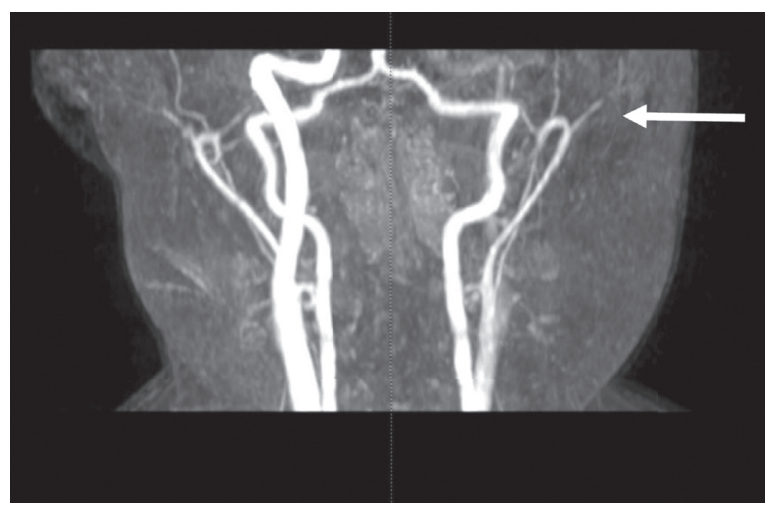

(b)

FIGURE 2: Brain neuroimaging results. (a) MRI: ischemic injury in the left frontoparietal region. (b) MRA: stenosis tightened by the left ICA and the thinning and irregularity of the left MCA.

TABLE 2: Pediatric case reports on CAD associated with minor head/cervical trauma.

\begin{tabular}{|c|c|c|c|c|c|}
\hline Author/year & $\begin{array}{c}\text { No. of } \\
\text { patients }\end{array}$ & Age & Cause of injury & Symptoms & $\begin{array}{l}\text { MRI or CT } \\
\text { images }\end{array}$ \\
\hline $\begin{array}{l}\text { Borges et al. } \\
(2000)[16]\end{array}$ & 2 & $\begin{array}{l}16 \text { years } \\
4 \text { years }\end{array}$ & Intraoral trauma & $\begin{array}{l}\text { Left hemiparesis, somnolence, confusion } \\
\text { Left hemiparesis, aphasia }\end{array}$ & $\begin{array}{l}\text { Infarct/right } \\
\mathrm{MCA} \\
\text { Infarct/left } \\
\text { ICA } \\
\end{array}$ \\
\hline $\begin{array}{l}\text { Bar et al. (2002) } \\
{[17]}\end{array}$ & 1 & 9 years & Intraoral trauma & Right hemiparesis, aphasia & $\begin{array}{l}\text { Infarct/left } \\
\text { ICA }\end{array}$ \\
\hline $\begin{array}{l}\text { Payton et al. } \\
(2004)[18]\end{array}$ & 1 & 11 years & Bumped head & $\begin{array}{c}\text { Slurred speech and headache, tongue deviated to } \\
\text { the right side and eyes deviated to the left, } \\
\text { dysarthria, confusion }\end{array}$ & $\begin{array}{l}\text { Infarct/left } \\
\text { ICA }\end{array}$ \\
\hline $\begin{array}{l}\text { Agner and Weig } \\
(2005)[19]\end{array}$ & 2 & $\begin{array}{c}4 \\
\text { months }\end{array}$ & Child abuse & $\begin{array}{l}\text { Seizures, left gaze unsteady gait, tremors in the right } \\
\text { arm }\end{array}$ & $\begin{array}{l}\text { Infarct/left } \\
\text { ICA }\end{array}$ \\
\hline $\begin{array}{l}\text { Pierrot et al. } \\
(2006)[20]\end{array}$ & 2 & $\begin{array}{l}4.5 \text { years } \\
3.5 \text { years }\end{array}$ & Fall & $\begin{array}{l}\text { Confusion, left hemiplegia, central facial nerve } \\
\text { palsy } \\
\text { Asymptomatic }\end{array}$ & $\begin{array}{c}\text { Infarct/right } \\
\text { ICA } \\
\text { No infarct/ } \\
\text { right ICA } \\
\end{array}$ \\
\hline $\begin{array}{l}\text { Jariwala et al. } \\
(2006)[21]\end{array}$ & 1 & 17 years & Motor vehicle accident & $\begin{array}{l}\text { Increased confusion, lack of strength, sensation of } \\
\text { the entire left upper extremity }\end{array}$ & $\begin{array}{l}\text { Infarct/right } \\
\text { ICA }\end{array}$ \\
\hline $\begin{array}{l}\text { Lin et al. (2007) } \\
{[22]}\end{array}$ & 1 & 7 years & Water slide injury & $\begin{array}{l}\text { Headache, vomiting, neck pain, facial palsy, } \\
\text { hemiplegia, and slurred speech }\end{array}$ & $\begin{array}{l}\text { Infarct/right } \\
\text { ICA }\end{array}$ \\
\hline $\begin{array}{l}\text { Levack et al. } \\
(2009)[23] \\
\end{array}$ & 1 & 14 years & Shoulder belt & Right hemiplegia and aphasia & $\begin{array}{l}\text { Infarct/right } \\
\text { CCA }\end{array}$ \\
\hline $\begin{array}{l}\text { Moriarty et al. } \\
(2009)[24]\end{array}$ & 1 & $\begin{array}{c}10 \\
\text { months }\end{array}$ & Intraoral trauma & Decreased level of consciousness, weakness & $\begin{array}{l}\text { Infarct/left } \\
\text { MCA }\end{array}$ \\
\hline \multirow{2}{*}{$\begin{array}{l}\text { Agostini et al. } \\
\text { (2013) [7] }\end{array}$} & \multirow[t]{2}{*}{2} & 7 years & $\begin{array}{l}\text { Violent head } \\
\text { hyperextension-rotation } \\
\text { episodes }\end{array}$ & Irritability, right-sided weakness & $\begin{array}{l}\text { Infarct/left } \\
\text { MCA }\end{array}$ \\
\hline & & 2 years & Vigorous somersaults & Headache and visual trouble & $\begin{array}{l}\text { Infarct/left } \\
\text { ICA }\end{array}$ \\
\hline $\begin{array}{l}\text { Nouh et al. } \\
(2015)[25]\end{array}$ & 1 & 4 years & Roller coaster ride & Left-sided weakness and left facial drop & $\begin{array}{c}\text { Infarct/right } \\
\text { MCA }\end{array}$ \\
\hline $\begin{array}{l}\text { Akbas et al. } \\
(2016)[26] \\
\end{array}$ & 1 & 5 years & Water slide use & Slurring of speech, right-sided weakness & $\begin{array}{l}\text { Infarct/left } \\
\text { ICA }\end{array}$ \\
\hline $\begin{array}{l}\text { Bent et al. } \\
(2016) \text { [27] }\end{array}$ & 1 & $\begin{array}{c}16 \\
\text { months }\end{array}$ & Intraoral trauma & $\begin{array}{l}\text { Diminished left extremity movement, dysconjugate } \\
\text { gaze, fluctuating mental status }\end{array}$ & $\begin{array}{l}\text { Infarct/right } \\
\text { ICA }\end{array}$ \\
\hline $\begin{array}{l}\text { Zant et al. } \\
(2017)[4]\end{array}$ & 1 & 4 years & Minor head trauma & Encephalopathy and left-sided hemiplegia & $\begin{array}{c}\text { Infarct/right } \\
\text { MCA and ICA }\end{array}$ \\
\hline $\begin{array}{l}\text { Cebeci et al. } \\
(2018)[6]\end{array}$ & 1 & 10 years & Minor shoulder trauma & Dysphasia, facial palsy & $\begin{array}{l}\text { No infarct/ } \\
\text { right ICA }\end{array}$ \\
\hline
\end{tabular}


account the long time elapsed between the beginning of the first clinical signs and the access to our department. The clinical outcome was good with a fast and progressive arterial revascularization. Moreover, we started an antiepileptic therapy with levetiracetam because of its neuroprotective properties in both epileptic and nonepileptic conditions and its frequent use in the prevention of poststroke epilepsy in adults $[30,31]$.

\section{Conclusion}

CAD in childhood is a rare event, but it can be the consequence of a minor trauma. In suspected cases, the lesion can be safely detected through brain MRI/MRA. Despite treatment options which are not yet standardized in children, in our patient, both the antiplatelet and the neuroprotective therapies were useful to reach a final favorable outcome and no long-term complications. However, more studies on the therapeutic management of stroke and CAD in the pediatric population are needed. This clinical case allowed us to underline how the dissection of carotid and vertebral arteries is probably an underdiagnosed pathology in children. Despite the lack of treatment guidelines, according to our experience, we always suggest to include the ICA dissection in the differential diagnosis of a child presenting with mild neurologic deficits after a cervical trauma, especially if they are associated with headache and/ or cervical pain.

\section{Data Availability}

All the data generated or analyzed during this study are included within this article and its supplementary information files. The data supporting this systematic review are from previously reported studies and datasets, which have been cited. The processed data are available in the supplementary file and from the corresponding author upon request.

\section{Ethical Approval}

This study adhered to the ethical guidelines for medical and health research involving human subjects established by the government of Italy.

\section{Consent}

Written consent for the publication of data and images was obtained from the parents of the patients.

\section{Conflicts of Interest}

The authors declare that they have no conflicts of interest.

\section{Authors' Contributions}

GC, EC, and LI contributed to the conception and design. $\mathrm{VL}, \mathrm{LM}$, and IF contributed to the acquisition and interpretation of the data. BP and LI revised and edited the manuscript. All the authors drafted the article and approved its final version.

\section{References}

[1] S. Debette, A. Compter, M.-A. Labeyrie et al., "Epidemiology, pathophysiology, diagnosis, and management of intracranial artery dissection," The Lancet Neurology, vol. 14, no. 6, pp. 640-654, 2015.

[2] R. J. Felling, L. R. Sun, E. C. Maxwell, N. Goldenberg, and T. Bernard, "Pediatric arterial ischemic stroke: epidemiology, risk factors, and management," Blood Cells, Molecules, and Diseases, vol. 67, pp. 23-33, 2017.

[3] M. Nash and M. F. Rafay, "Craniocervical arterial dissection in children: pathophysiology and management," Pediatric Neurology, vol. 95, pp. 9-18, 2019.

[4] R. Zant, M. Melter, C. Doerfler et al., "Carotid artery dissection with associated territory stroke after a minor head trauma in a healthy 4-month-old child," Pediatric Emergency Care, vol. 33, no. 12, 2017.

[5] A. Stacey, C. Toolis, and V. Ganesan, "Rates and risk factors for arterial ischemic stroke recurrence in children," Stroke, vol. 49, no. 4, pp. 842-847, 2018.

[6] D. Cebeci, E. Arhan, E. Demir et al., "Internal carotid artery dissection without intracranial infarct following a minor shoulder trauma: the second pediatric case and review of the literature," Journal of Clinical Neuroscience, vol. 56, pp. 172-175, 2018.

[7] M. Agostini, M. M. Lupica, M. Mostert, N. Deluca, and L. Cordero di Montezemolo, "Cervical arterial dissection and ischaemic stroke in children: two cases," Acta Paediatrica, vol. 102, no. 4, pp. e142-e146, 2013.

[8] M. M. Mortazavi, K. Verma, R. S. Tubbs, and M. Harrigan, "Pediatric traumatic carotid, vertebral and cerebral artery dissections: a review," Child's Nervous System, vol. 27, no. 12, pp. 2045-2056, 2011.

[9] G. Orman, A. Tekes, A. Poretti, C. Robertson, and T. A. G. M. Huisman, "Posttraumatic carotid artery dissection in children: not to be missed!" Journal of Neuroimaging, vol. 24, no. 5, pp. 467-472, 2014.

[10] J. M. Provenzale and B. Sarikaya, "Comparison of test performance characteristics of MRI, MR angiography, and CT angiography in the diagnosis of carotid and vertebral artery dissection: a review of the medical literature," American Journal of Roentgenology, vol. 193, no. 4, pp. 1167-1174, 2009.

[11] W. J. Powers, A. A. Rabinstein, T. Ackerson et al., "Guidelines for the early management of patients with acute ischemic stroke: 2019 update to the 2018 guidelines for the early management of acute ischemic stroke a guideline for healthcare professionals from the American Heart Association/American Stroke Association," Stroke, vol. 5, no. 12, pp. 344-418, 2019.

[12] D. M. Ferriero, H. J. Fullerton, T. J. Bernard et al., "Management of stroke in neonates and children: a scientific statement from the American Heart Association/American Stroke Association," Stroke, vol. 50, no. 3, pp. 51-96, 2019.

[13] P. M. Rothwell, A. Algra, Z. Chen, H.-C. Diener, B. Norrving, and Z. Mehta, "Effects of aspirin on risk and severity of early recurrent stroke after transient ischaemic attack and ischaemic stroke: time-course analysis of randomised trials," The Lancet, vol. 388, no. 10042, pp. 365-375, 2016.

[14] H. S. Markus, E. Hayter, C. Levi et al., "Antiplatelet treatment compared with anticoagulation treatment for cervical artery 
dissection (CADISS): a randomised trial," The Lancet Neurology, vol. 14, no. 4, pp. 361-367, 2015.

[15] R. B. Chamoun, M. E. Mawad, W. E. Whitehead, T. G. Luerssen, and A. Jea, "Extracranial traumatic carotid artery dissections in children: a review of current diagnosis and treatment options," Journal of Neurosurgery: Pediatrics, vol. 2, no. 2, pp. 101-108, 2008.

[16] G. Borges, L. Bonilha, S. F. Santos et al., "Thrombosis of the internal carotid artery secondary to soft palate injury in children and childhood," Pediatric Neurosurgery, vol. 32, no. 3, pp. 150-153, 2000.

[17] T. Bar, A. Zagury, O. Nahlieli, D. London, B. Yoffe, and H. Bibi, "Delayed signs and symptoms after oropharyngeal trauma in a child," Oral Surgery, Oral Medicine, Oral Pathology, Oral Radiology, and Endodontology, vol. 94, no. 1, pp. 15-17, 2002.

[18] T. F. Payton, K. M. Siddiqui, D. P. Sole, and D. F. Mckinley, "Traumatic dissection of the internal carotid artery," Pediatric Emergency Care, vol. 20, no. 1, pp. 27-29, 2004.

[19] C. Agner and S. G. Weig, "Arterial dissection and stroke following child abuse: case report and review of the literature," Child's Nervous System, vol. 21, no. 5, pp. 416-420, 2005.

[20] S. Pierrot, D. Bernardeschi, M.-P. Morrisseau-Durand, Y. Manach, and V. Couloigner, "Dissection of the internal carotid artery following trauma of the soft palate in children," Annals of Otology, Rhinology \& Laryngology, vol. 115, no. 5, pp. 323-329, 2006.

[21] S. P. Jariwala, J. G. Crowley, and S. Roychowdhury, "Traumainduced extracranial internal carotid artery dissection leading to multiple infarcts in a young girl," Pediatric Emergency Care, vol. 22, no. 10, pp. 737-742, 2006.

[22] J.-J. Lin, M.-L. Chou, K.-L. Lin, M.-C. Wong, and H.-S. Wang, "Cerebral infarct secondary to traumatic carotid artery dissection," Pediatric Emergency Care, vol. 23, no. 3, pp. 166-168, 2007.

[23] M. M. Levack, B. J. Pettitt, and A. D. Winston, "Carotid artery thrombosis and delayed stroke associated with the use of a shoulder belt in a teenager," Journal of Pediatric Surgery, vol. 44, no. 8, pp. 29-33, 2009.

[24] J. M. Moriarty, C. Lukas, L. Rossler, C. Thiels, and R. Drescher, "Carotid artery dissection following a minor household accident in a 10-month-old child," Irish Journal of Medical Science, vol. 178, no. 4, pp. 535-539, 2009.

[25] A. Nouh, D. Vela-Duarte, T. Grobelny, G. Hoganson, D. Pasquale, and J. Biller, "Internal carotid artery dissection after a roller coaster ride in a 4-year-old: case report and review of the literature," Pediatric Neurology, vol. 52, no. 3, pp. 349-351, 2015.

[26] Y. Akbaş, E. Arhan, A. Serdaroglu, and B. Nazlıel, "Intracranial internal carotid artery dissection following waterslide use: the first case report," Child's Nervous System, vol. 32, no. 3, pp. 411-413, 2016.

[27] C. Bent, P. Shen, B. Dahlin, and K. Coulter, "Blunt intraoral trauma resulting in internal carotid artery dissection and infarction in a child," Pediatric Emergency Care, vol. 32, no. 8, pp. 534-535, 2016.

[28] K. Moon, F. C. Albuquerque, T. Cole, B. A. Gross, and C. G. McDougall, "Stroke prevention by endovascular treatment of carotid and vertebral artery dissections," Journal of NeuroInterventional Surgery, vol. 9, no. 10, pp. 952-957, 2017.

[29] A. Camacho, A. Villarejo, A. Martinez de Aragón, R. Simón, and F. Mateos, "Spontaneous carotid and vertebral artery dissection in children," Pediatric Neurology, vol. 25, no. 3, pp. 250-253, 2001.

[30] V. Belcastro, L. Pierguidi, and N. Tambasco, "Levetiracetam in brain ischemia: clinical implications in neuroprotection and prevention of post-stroke epilepsy," Brain and Development, vol. 33, no. 4, pp. 289-293, 2011.

[31] A. K. Shetty, "Prospects of levetiracetam as a neuroprotective drug against status epilepticus, traumatic brain injury, and stroke," Frontiers in Neurology, vol. 4, Article ID 172, 2013. 